\title{
Effects of dignity therapy on terminally ill patients: a systematic review*
}

\section{Efeitos da terapia da dignidade para pacientes em fase final de vida: revisão sistemática Efectos de la terapia dignidad para pacientes en fase final de vida: revisión sistemática}

\section{Suzana Cristina Teixeira Donato¹, Jéssica Yumi Matuoka², Camila Cristófero Yamashita ${ }^{3}$, Marina de Goés Salvetti ${ }^{4}$}

\section{How to cite this article:}

Donato SCT, Matuoka JY, Yamashita CC, Salvetti MG. Effects of dignity therapy on terminally ill patients: a systematic review. Rev Esc Enferm USP. 2016;50(6):1011-1021. DOI: http://dx.doi.org/10.1590/S0080-623420160000700019

* Extracted from the concluding residency work "Efeitos da terapia da dignidade para pacientes em fase final de vida: revisão sistemática", Programa de Residência em Enfermagem na Saúde do Adulto e Idoso, Escola de Enfermagem/Hospital Universitário, Universidade de São Paulo, 2016.

${ }^{1}$ Universidade de São Paulo, Escola de Enfermagem, São Paulo, SP, Brazil.

${ }^{2}$ Universidade de São Paulo, Escola de Enfermagem, Programa de Pós-Graduação em Saúde do Adulto, São Paulo, SP, Brazil.

${ }^{3}$ Instituto do Câncer do Estado de São Paulo, Serviço de Cuidados Paliativos, São Paulo, SP, Brazil.

${ }^{4}$ Universidade de São Paulo, Escola de Enfermagem, Departamento de Enfermagem Médico-Cirúrgica, São Paulo, SP, Brazil.

\section{ABSTRACT}

Objective: Analyzing the evidence of the effects of dignity therapy on terminally ill patients. Method: A Systematic review of the literature conducted using the search strategy in six databases. Inclusion criteria were primary studies, excluding literature reviews (systematic or not) and conceptual articles. Results: Ten articles were analyzed regarding method, results and evidence level. Dignity therapy improved the sense of meaning and purpose, will to live, utility, quality of life, dignity and family appreciation in studies with a higher level of evidence. The effects are not well established in relation to depression, anxiety, spirituality and physical symptoms. Conclusion: Studies with a moderate to high level of evidence have shown increased sense of dignity, will to live and sense of purpose. Further studies should be developed to increase knowledge about dignity therapy.

\section{DESCRIPTORS}

Palliative Care; Terminally Ill; Psychotherapy, Brief; Quality of Life; Holistic Nursing; Review. 


\section{INTRODUCTION}

The term dignity was defined by the philosopher Immanuel Kant in the study Groundwork of the Metaphysics of Morals, where he dissected the concept of dignity from the realm of religiosity by bringing it into the political and social realm, defining it as an irreplaceable value that coats all people, devoid of religious value ${ }^{(1)}$. In this respect, it is an intrinsic quality of human beings, since they have autonomy in exercising practical reasoning as each individual has distinct individual and indispensable personalities. The author claims that autonomy and dignity are distinct concepts, however, inseparable in the exercise of practical reason, and concluding that for this reason, only human beings can be coated with dignity ${ }^{(1)}$.

Many authors have discussed the term dignity throughout history; however, in a generic way, without portraying aspects of terminally ill patients. In the middle of 1991, a year in which the study Euthanasia and other medical decisions concerning the end of life ${ }^{(2)}$ was developed, the term dignity began to be related to some issues of patients with incurable diseases. In this study, loss of dignity appeared as the motivating factor for the choice of euthanasia or assisted suicide in $57 \%$ of patients who had opted for this outcome ${ }^{(2)}$. For the first time, loss of dignity was related to important decisions at the end of life, demonstrating the need to bring the theme of dignity into the context of terminality.

In 2002, a study investigated variables that interfered with the dignity of terminally ill patients and showed that $54 \%$ of the patients had a strong or intact sense of dignity, $46 \%$ reported that they had occasional and slight concerns about their dignity, and 7.5\% reported that a loss of dignity was a serious problem in their lives, often associated with feelings of degradation and shame ${ }^{(3)}$.

The group of patients with threatened dignity presented lower quality of life and satisfaction, being associated with depression, anxiety, hopelessness and a greater desire for anticipation of death ${ }^{(3)}$. Issues of deterioration of appearance, the feeling of being a burden, the need to be assisted during activities of daily living were related to loss of personal competence, autonomy and loss of personal identity, impacting on the sense of dignity ${ }^{(3)}$. Study participants were being followed by palliative care programs of excellence, which may have directly influenced the smaller number of patients who reported a problem related to aspects of dignity.

Another research has shown how patients diagnosed with advanced cancer conceived the term dignity, providing the basis for developing a conceptual model of dignity. Issues that could increase or decrease patients' sense of dignity were: the behaviors of family members, friends and health professionals, aspects that provided meaning to life, essential activities, their own philosophies and feelings such as pride, self-respect, quality of life, well-being, hope and self-esteem. At the end of the study the authors proposed a conceptual model of dignity, arranged in three fundamental categories: concerns related to the disease (physical and psychological symptoms), personal resources of dignity (psychological and or spiritual factors that influence the sense of dignity) and social resources of dignity (social context, encompassing positive aspects, challenges and suffering $)^{(4)}$.

The model was proposed with the objective of defining physical, spiritual and psychosocial issues of terminally ill patients with some degree of impairment of dignity and, thus, improving the quality of life of these patients. From this conceptual model, Dignity Therapy (DT) was created by Chochinov in 2005, a psychotherapeutic intervention developed to give meaning to questions fostering psychosocial and existential anguish/suffering, with a brief and individualized approach that allows patients to discuss the most important individual issues for constructing a legacy document that can be remembered after imminent death ${ }^{(5)}$.

As the main contribution of therapy is the building of a legacy, patients are guided by a therapist (a trained health professional) to raise important questions - wishes, memories and/or unfinished business - audio recorded by the professional, who subsequently transcribes and edits them in the form of a document, and according to the patient's choice it can be delivered during their life or after their death to relatives or other loved ones ${ }^{(6)}$. The palliative care team can also make use of this material to better understand end-of-life issues and provide care focused on the specifics of each patient.

Through these studies, we have hypothesized that loss of dignity may diminish as terminally ill patients are cared for in a comprehensive environment with quality support that provides holistic care associated to a symptomatic effective treatment; considering that the preservation of dignity is related to the care provided, the sensitivity of health professionals and caregivers, and the intensity of care $^{(6)}$.

According to the World Health Organization, palliative care strategy should be developed by a multiprofessional team that focuses attention not on the disease to be cured/ controlled, but on the patient/person, who are understood as active biographical beings, with the right to information and full autonomy for decisions regarding their treatment. The care must be individualized to the patient and their family, in order to obtain control of all symptoms and to prevent suffering ${ }^{(7)}$.

Data from the National Cancer Institute show that 596 thousand new cases of cancer are estimated in Brazil in $2016^{(8)}$. According to IBGE (Instituto Brasileiro de Geografia e Estatistica), in 2050 there will be more older adults than children under 15 years of age. In 2012, the world population had 810 million people aged 60 and over, making up 11.5\% of the global population. Projections indicate that in 2050 older adults will make up $22 \%$ of the global population ${ }^{(9)}$. Furthermore, according to a study published in 2014, the most frequent causes of death in Brazil are cardiovascular diseases (30.4\%), neoplasias (16.4\%), respiratory diseases $(6 \%)$ and diabetes $(5.3 \%)^{(10)}$. Thus, many patients need or will need a palliative approach and, since the WHO advocates that all issues of care should be addressed, including spiritual, psychosocial and family (issues), therapies that address these aspects may be significant in palliative care ${ }^{(7)}$.

Considering the prevalence of terminally ill patients and that they have problems regarding dignity and its physical, emotional and psychosocial consequences, the objective of 
this study is to analyze evidence on the effects of Dignity Therapy on terminally ill patients. To meet this goal, the following research question was formulated: What are the physical, spiritual, and psychosocial effects of dignity therapy for terminally ill patients?

\section{METHOD}

This is a systematic review of the literature following the recommendations of the Preferred Reporting Items for Systematic Reviews and Meta-Analysis (PRISMA) guideline ${ }^{(11-13)}$. The PICO strategy was used to guide the research, in which $\mathrm{P}$ refers to the patient (terminally ill patients), I to the intervention (dignity therapy), $\mathrm{C}$ to the comparison (comparison with other interventions, as a search strategy was not used), $\mathrm{O}$ to the outcomes (physical, spiritual and psychosocial effects of dignity therapy). The searches were conducted from August to December 2015(11-13).

Searches were carried out in six databases, namely: CINAHL, COCHRANE, LILACS, PubMed, SCOPUS, and WEB OF SCIENCE, in addition to articles found through manual searching in other sources such as free searches on Google Scholar and those found in the references of the analyzed articles, providing they met the inclusion criteria. The descriptors used in the search were selected through DeCS (descriptors in health sciences), $\mathrm{MeSH}$ (Medical Subject Headings) and CINAHL (Cumulative Index to Nursing and Allied Health Literature).

Chart 1 shows how the descriptors were used for each element of the PICO acronym.

Chart 1 - Descriptors for each element according to the PICO strategy - São Paulo, 2015/2016.

\begin{tabular}{|l|l|l|}
\hline & \multicolumn{1}{|c|}{ CONTROLLED DESCRIPTORS } & \multicolumn{1}{|c|}{$\begin{array}{c}\text { UNCONTROLLED } \\
\text { DESCRIPTORS }\end{array}$} \\
\hline $\mathbf{P}$ & $\begin{array}{l}\text { Palliative care, terminally ill, } \\
\text { terminal care, hospice care, } \\
\text { hospice and palliative care nursing. } \\
\text { CINAHL - "hospice and palliative } \\
\text { nursing". }\end{array}$ & $\begin{array}{l}\text { Palliative Care, } \\
\text { Terminally Ill, terminal } \\
\text { care, hospice care, } \\
\text { hospice and palliative } \\
\text { care nursing. }\end{array}$ \\
\hline $\mathbf{I}$ & $\begin{array}{l}\text { Living will, psychotherapy, brief } \\
\text { psychotherapy. }\end{array}$ & $\begin{array}{l}\text { Dignity therapy, living } \\
\text { will, psychotherapy, brief } \\
\text { psychotherapy. }\end{array}$ \\
\hline $\mathbf{C}$ & \multicolumn{1}{c}{-} \\
\hline $\mathbf{O}$ & Quality of life. & Quality of life. \\
\hline
\end{tabular}

To broaden the reach to studies of interest, the search strategy included controlled and uncontrolled descriptors combined with each other, as described below: "Palliative Care" OR "Hospice Care" OR "Hospice and Palliative Care Nursing" OR "Terminal Care" OR "Terminally Ill” AND "Living Wills" OR "Psychotherapy" OR "Psychotherapy, Brief" OR "dignity therapy" AND "Quality of Life".

The level of evidence was classified according to the GRADE system (Grading of Recommendations Assessment, Development and Evaluation), which covers a number of recommendations that guide the process of assessing the quality of evidence from studies included in systematic reviews. The scores range from 1 to 4 , according to the level of evidence: 1 - very low, 2 -low, 3 - moderate and 4 - high.
Randomized controlled trials have a higher level of evidence and non-randomized studies receive lower scores. Factors that may decrease the quality of evidence are: bias risk (I), inconsistency (II), indirect evidence (III), imprecision (IV) and publication bias $(\mathrm{V})$; and factors that may increase the level of evidence are related to magnitude of effect (effect size (VI), dose-response gradient (VII) and possible residual confusion (VIII) ${ }^{(14)}$.

Randomized and controlled clinical trials have a therapeutic focus and provide the best scientific evidence, since randomization of subjects for allocation in study groups is the best way to make groups similar and comparable, reducing risk of bias. In quasi-experimental studies, however, there is no group comparison and the same subjects are evaluated before and after the experiment. Although quasi-experimental studies also bring relevant information, the evidence produced is more fragile because the patient is their only control ${ }^{(12)}$.

According to the GRADE System guidelines ${ }^{(14)}$, randomized clinical trials have high levels of evidence (4 points) and they can gain or lose points according to the analysis of the items that are recommended in the trials. Nonrandomized studies begin the analysis with a lower level of evidence and can gain or lose points according to an evaluation of the methodological quality, for example, nonrandomized studies may increase points if they present a large magnitude of effect ${ }^{(14)}$. Thus, a high level of evidence means that the effect estimate and the true effect are close; in the case of moderate evidence, the true effect is likely to be close to the effect estimate, but there is a possibility of it being substantially different. In low and very low evidence, we have limited and little confidence in the estimation of the effect, respectively.

The inclusion criteria used were: primary studies that addressed the effects of dignity therapy, with a sample composed of adults (18 years of age or older). Articles in Portuguese, English or Spanish. Exclusion criteria were: literature reviews (systematic or not) and conceptual studies. The studies that met the inclusion criteria and answered the research question were selected for analysis in their entirety.

\section{RESULTS}

The searches resulted in retrieval of 1,111 articles and 12 other articles were found by a manual search from other sources. Of these, 979 were excluded by the title for not being related to the subject, and 54 duplicates were removed. After reading the abstracts, 56 were selected for full readings; 19 were excluded because they were not directly related to the subject; 25 more were excluded because they were conceptual studies and two articles were excluded because they addressed the effects of DT in patients with motor neuron disease (MND). The objective of the review was to analyze the effects of DT on terminally ill patients and MND is not a terminal illness, so the studies were excluded, although they represented innovative therapy application originally proposed by Chochinov ${ }^{(4-5)}$. Finally, 10 studies remained, which were included in the final analysis of the review. The study selection process is presented via flowchart in Figure 1, 
and this is an adaptation of the self-fill out model proposed by the PRISMA guideline ${ }^{(11-12)}$.

The articles analyzed were published between 2005 and 2015. Of the studies selected, 80\% were found in PubMed,
$10 \%$ in SCOPUS and 10\% in COCHRANE. No studies were selected in the searches performed in LILACS, CINAHL, WEB OF SCIENCE or through a manual search.
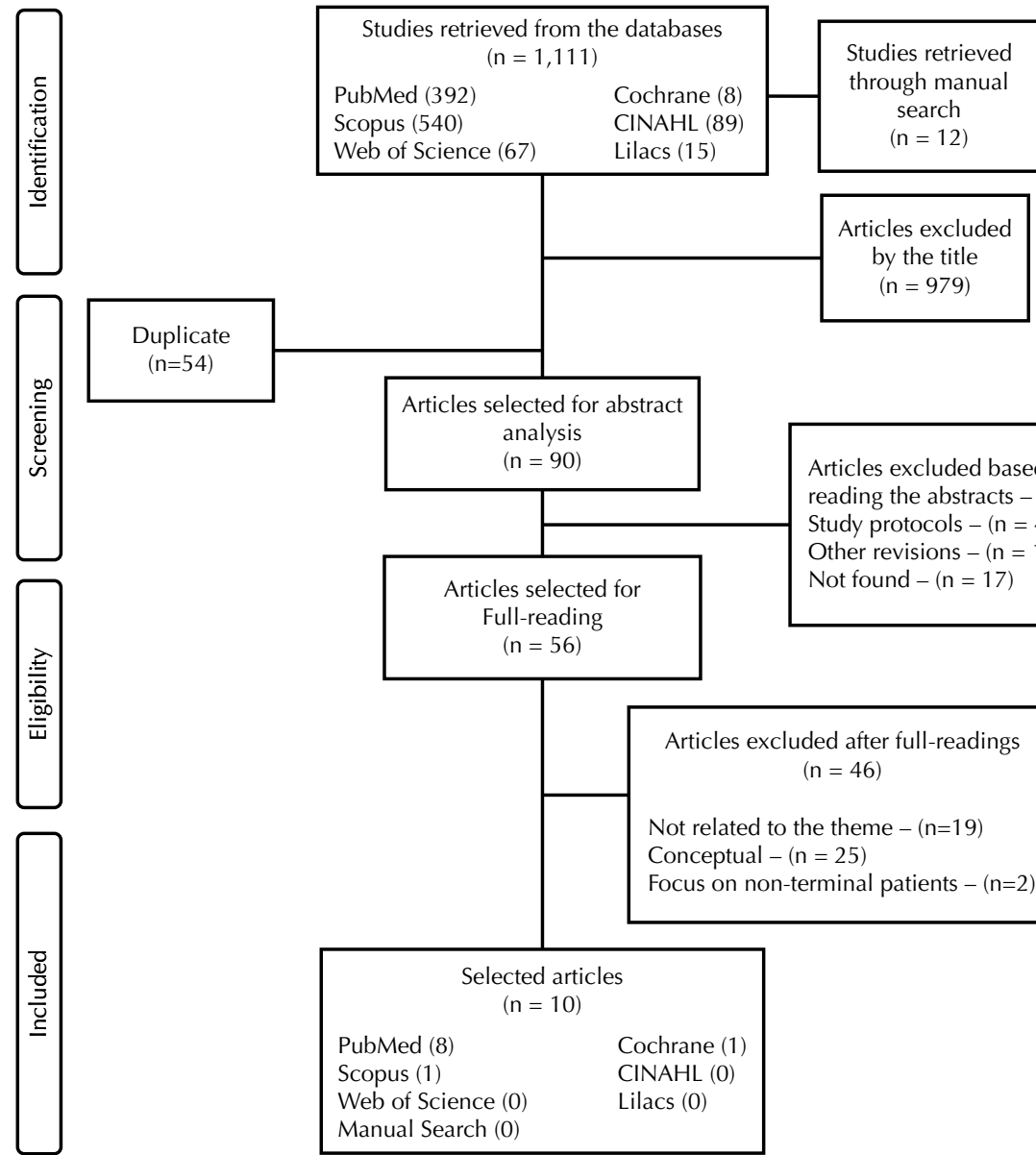

Figure 1 - Flowchart of selection of the articles of the Systematic Review, according to PRISMA(11-12) - São Paulo, 2015/2016.

The characterization of the studies included in the review is summarized in Chart 2, and is organized according to author/ year/place, type of study, objectives, sample, and results. The studies were grouped according to the patients' profile and are discussed below. The studies included for analysis in the review were grouped according to the location in which the patients were approached for the application of the interventions, and were listed from A1 to A10 for better organization of the results. In other words, group 1 gathered studies in which the patients were hospitalized (A1 and A2) ${ }^{(6,15)}$, group 2 studies include outpatients (A3 to A7) ${ }^{(16-20)}$, and group 3 studies included inpatients and outpatients (A8 to $A 10)^{(5,21-22)}$.

Chart 2 - Characterization of articles included in the review - São Paulo, 2015.

\begin{tabular}{|c|c|c|c|c|c|}
\hline & $\begin{array}{c}\text { Author/ } \\
\text { year/place } \\
\text { of study }\end{array}$ & $\begin{array}{l}\text { Type of } \\
\text { study }\end{array}$ & Goal & Sample & Results \\
\hline & \multicolumn{5}{|c|}{ Group 1 - Patients in palliative care with advanced/terminal disease in hospitalization unit } \\
\hline A1 & $\begin{array}{l}\text { Julião et al., } \\
2013- \\
\text { Portuga|(6) }\end{array}$ & $\begin{array}{l}\text { Randomized } \\
\text { Clinical Trial }\end{array}$ & $\begin{array}{l}\text { Determine the } \\
\text { effects of DT on } \\
\text { the symptoms of } \\
\text { depression and } \\
\text { anxiety in patients } \\
\text { with high level of } \\
\text { suffering. }\end{array}$ & $\begin{array}{l}\mathrm{n}=60 \text { terminal patients } \\
\text { with life expectancy } \leq \\
6 \text { months. Submitted } \\
\text { to DT associated with } \\
\text { palliative care }(\mathrm{n}=29) \\
\text { and palliative care } \\
(\mathrm{n}=31) ; \\
95 \% \text { cancer and } 5 \% \\
\text { with non-malignant } \\
\text { terminal conditions. }\end{array}$ & $\begin{array}{l}\text { Patients undergoing DT showed a decrease in } \\
\text { depression score on the fourth day }(p=0.001) \text {, } \\
\text { maintained on the } 15^{\text {th }} \text { day }(p=0.022) \text {, but not on } \\
\text { the } 30^{\text {th }} \text { day }(p=0.097) \text {. Lower indices of anxiety } \\
\text { in all assessment periods }\left(4^{\text {th }} \text { day }-p=0.005,15^{\text {th }}\right. \\
\left.\text { day }-p=0.006,30^{\text {th }} \text { day }-p=0.054\right) \text {. Showed } \\
\text { improvements regarding anxiety and depression, } \\
\text { even in patients with high levels of suffering at the } \\
\text { beginning. As an improvement in depression is not } \\
\text { maintained until the } 30^{\text {th }} \text { day, it is hypothesized that } \\
\text { a single DT session may be insufficient. }\end{array}$ \\
\hline
\end{tabular}

continued... 


\begin{tabular}{|c|c|c|c|c|c|}
\hline & $\begin{array}{l}\text { Author/ } \\
\text { year/place } \\
\text { of study }\end{array}$ & $\begin{array}{l}\text { Type of } \\
\text { study }\end{array}$ & Goal & Sample & Results \\
\hline \multirow[t]{2}{*}{ A2 } & $\begin{array}{l}\text { Julião et al., } \\
2014- \\
\text { Portugal }^{(15)}\end{array}$ & $\begin{array}{l}\text { Randomized } \\
\text { Clinical Trial }\end{array}$ & $\begin{array}{l}\text { Evaluate the } \\
\text { effectiveness of DT } \\
\text { on depression and } \\
\text { anxiety scores of } \\
\text { patients in palliative } \\
\text { care. }\end{array}$ & $\begin{array}{l}\mathrm{n}=80 \text { patients in } \\
\text { palliative care with life } \\
\text { expectancy } \leq 6 \text { months. } \\
\text { Submitted to DT } \\
(\mathrm{n}=39) \text { and palliative } \\
\text { care }(\mathrm{n}=41) ; \\
92.5 \% \text { cancer and } 7.5 \% \\
\text { with non-malignant } \\
\text { terminal conditions. }\end{array}$ & $\begin{array}{l}\text { Patients undergoing DT showed a decrease in } \\
\text { depression score in all periods of the evaluation } \\
\text { in relation to the control group }\left(4^{\text {th }} \text { day }-p<\right. \\
\left.0.0001,15^{\text {th }} \text { day }-p=0.010,30^{\text {th }} \text { day }-p=0.043\right) \text {. } \\
\text { There was a significant decrease in anxiety for all } \\
\text { periods }\left(4^{\text {th }} \text { day }-p<0.0001,15^{\text {th }} \text { day }-p=0.001 \text {, }\right. \\
\left.30^{\text {th }} \text { day }-p=0.003\right) \text {. DT showed improvements } \\
\text { regarding anxiety and depression, even in patients } \\
\text { with high levels of suffering at the beginning of the } \\
\text { study. The improvements also showed a sustained } \\
\text { effect (until the } 30^{\text {th }} \text { day). }\end{array}$ \\
\hline & \multicolumn{5}{|c|}{ Group 2 - Outpatients/patients in palliative care with advanced/terminal disease } \\
\hline A3 & $\begin{array}{l}\text { Hall et al., } \\
2011- \\
\text { England }^{(16)}\end{array}$ & $\begin{array}{l}\text { Randomized } \\
\text { Clinical Trial }\end{array}$ & $\begin{array}{l}\text { Assess the feasibility, } \\
\text { acceptability and } \\
\text { potential effectiveness } \\
\text { of dignity therapy } \\
\text { in reducing } \\
\text { psychological and } \\
\text { spiritual suffering of } \\
\text { elderly people. }\end{array}$ & $\begin{array}{l}\mathrm{n}=60 \text { elderly people } \\
\text { in nursing homes. } \\
\text { Submitted to palliative } \\
\text { care }(\mathrm{n}=29) \text { and DT } \\
(\mathrm{n}=31) ; \\
\text { With oncological } \\
\text { diseases and not at an } \\
\text { advanced oncological } \\
\text { terminal stage (with } \\
\text { an average survival } \\
\text { of } 6 \text { month in the } \\
\text { intervention group). }\end{array}$ & $\begin{array}{l}\text { There were no significant differences in the potential } \\
\text { measures of effectiveness between interventions. The } \\
\text { DT presented small effects in relation to depression } \\
\text { and quality of life } 1 \text { week after the intervention. } \\
\text { Acceptability: the variables make life more meaningful } \\
\text { and serve as an aid to the families, showing significant } \\
\text { improvement }(p=0.04 \text { and } p=0.02 \text {, respectively) } \\
\text { on the first assessment, after } 8 \text { weeks only family } \\
\text { support remained significant ( } p=0.01) \text {. The DT was } \\
\text { higher relative to the size of the effect in the first } \\
\text { and second reviews, utility }(0.38-0.55) \text {, made life } \\
\text { more meaningful }(0.58-0.25) \text {, increased the sense of } \\
\text { purpose }(0.27-0.53) \text {, decreased suffering }(0.29-0.34) \text {, } \\
\text { increased the will to live }(0.46-0.39), \text { helped or would } \\
\text { help the family }(0.66-0.85) \text {. The document/legacy took } \\
\text { longer to be generated (about } 1-5 \text { visits). }\end{array}$ \\
\hline A4 & $\begin{array}{l}\text { Johns et al., } \\
2013- \\
\text { USA }^{(17)}\end{array}$ & $\begin{array}{l}\text { Quasi- } \\
\text { experimental } \\
\text { Study }\end{array}$ & $\begin{array}{l}\text { Evaluate the feasibility } \\
\text { of providing DT. }\end{array}$ & $\begin{array}{l}\mathrm{n}=10 \text { patients with } \\
\text { metastatic cancer; } 100 \% \\
\text { caucasian women with } \\
\text { stage IV metastatic } \\
\text { cancer (without } \\
\text { information on survival } \\
\text { time). }\end{array}$ & $\begin{array}{l}\text { Patients reported that DT was useful to them and } \\
\text { to their families; it increased their meaning of life, } \\
\text { their sense of dignity and decreased suffering (75\%). } \\
\text { With } 100 \% \text { satisfaction. Families and patients } \\
\text { considered the document/legacy very useful. The } \\
\text { levels of depression and satisfaction with quality of } \\
\text { life worsened. The transcripts of the document were } \\
\text { longer than other studies. }\end{array}$ \\
\hline A5 & $\begin{array}{l}\text { Vergo et al., } \\
2014- \\
\text { USA }^{(18)}\end{array}$ & $\begin{array}{l}\text { Quasi- } \\
\text { experimental } \\
\text { Study }\end{array}$ & $\begin{array}{l}\text { Evaluate the feasibility } \\
\text { of DT in patients with } \\
\text { colorectal cancer and } \\
\text { the changes in the } \\
\text { acceptance of death, } \\
\text { suffering, symptoms, } \\
\text { quality of life, } \\
\text { tranquility, and goals } \\
\text { of care at the end of } \\
\text { life and the treatment } \\
\text { options before and } \\
\text { after treatment with } \\
\text { DT for each patient. }\end{array}$ & $\begin{array}{l}\mathrm{n}=9 \text { patients with } \\
\text { colorectal cancer who } \\
\text { underwent palliative } \\
\text { chemotherapy; } \\
100 \% \text { with stage IV } \\
\text { metastatic cancer } \\
\text { (without survival time } \\
\text { information). }\end{array}$ & $\begin{array}{l}\text { Feasibility of DT: } 100 \% \text { satisfaction, } 88 \% \text { reported } \\
\text { usefulness of therapy and an increased sense of } \\
\text { purpose, } 78 \% \text { which increased sense of dignity } \\
\text { and purpose, } 67 \% \text { which increased the will to live. } \\
\text { Physical symptoms: appetite improvement after the } \\
\text { DT. Emotional symptoms: no changes presented. } \\
\text { Clinical outcomes: increased acceptance of death } \\
\text { (57\% post-DT), choice of care and treatments that } \\
\text { would not prolong life (58\% post-DT). }\end{array}$ \\
\hline A6 & $\begin{array}{l}\text { Rudilla } \\
\text { et al., } \\
2014- \\
\text { Spain }\end{array}$ & $\begin{array}{l}\text { Randomized } \\
\text { Clinical Trial }\end{array}$ & $\begin{array}{l}\text { Identify and quantify } \\
\text { the significant } \\
\text { differences in terms } \\
\text { of emotional distress, } \\
\text { quality of life and } \\
\text { preservation of } \\
\text { dignity after treatment } \\
\text { with dignity therapy } \\
\text { (DT) and counseling } \\
\text { therapy. }\end{array}$ & $\begin{array}{l}\mathrm{n}=30 \text { terminal patients } \\
\text { in hospice care with } \\
\text { advanced stage cancer; } \\
\text { Submitted to DT } \\
(\mathrm{n}=15) \text { and Therapeutic } \\
\text { counseling (TC) }(\mathrm{n}=15) ; \\
\text { Served at home. There is } \\
\text { no specification of the } \\
\text { survival time. }\end{array}$ & $\begin{array}{l}\text { In the comparison between the two therapies, there } \\
\text { were no statistically significant differences. Both } \\
\text { therapies were statistically significant for: decreasing } \\
\text { suffering (DT } p<0.001 \text { and TC } p=0.001 \text { ), increasing } \\
\text { of quality of life (DT } p=0.000 \text { and TC } p=0.009 \text { ), } \\
\text { decreasing existential suffering (DT } p=0.003 \text { and } \\
\text { TC } p=0.000 \text { ). }\end{array}$ \\
\hline A7 & $\begin{array}{l}\text { Rudilla } \\
\text { et al., } \\
2015- \\
\text { Spain }\end{array}$ & $\begin{array}{l}\text { Controlled } \\
\text { Trial }\end{array}$ & $\begin{array}{l}\text { Examine and } \\
\text { compare the effects } \\
\text { of dignity therapy } \\
\text { (DT) and advice on } \\
\text { meeting the needs of } \\
\text { the patient. }\end{array}$ & $\begin{array}{l}\mathrm{n}=70 \text { patients in } \\
\text { palliative care home } \\
\text { service with advanced } \\
\text { disease. Submitted to } \\
\text { Therapeutic counseling } \\
(\mathrm{n}=35) \text { and DT } \\
(\mathrm{n}=35) ; \\
\text { Oncological and non- } \\
\text { oncological diseases } \\
\text { (there is no specification } \\
\text { of survival time). }\end{array}$ & $\begin{array}{l}\text { In the pre-and post-intervention measures for DT, } \\
\text { there were statistically significant differences in } \\
\text { symptoms of pain, existential suffering, dependency, } \\
\text { peace of mind, social support, intrapersonal, } \\
\text { interpersonal and transpersonal spirituality, } \\
\text { reliable support and affective support }(p<0.001) \text {, } \\
\text { anxiety, depression }(p=0.001) \text { and quality of life } \\
(p=0.011) \text {. There were no significant differences } \\
\text { with regard to resilience }(p=0.058) \text {. Counseling } \\
\text { Therapy was superior to the DT regarding anxiety } \\
\text { ( } p=0.022) \text {. Also, analyzed in isolation obtained } \\
\text { good results regarding resilience }(p=0.005) \text {. }\end{array}$ \\
\hline
\end{tabular}


...continuation

\begin{tabular}{|c|c|c|c|c|c|}
\hline & $\begin{array}{c}\text { Author/ } \\
\text { year/place } \\
\text { of study }\end{array}$ & $\begin{array}{l}\text { Type of } \\
\text { study }\end{array}$ & Goal & Sample & Results \\
\hline & \multicolumn{5}{|c|}{ Group 3 - Admitted and non-admitted patients (inpatients/outpatients) in palliative care with advanced/terminal disease } \\
\hline A8 & $\begin{array}{l}\text { Chochinov } \\
\text { et al., } \\
2005- \\
\text { Canada }^{(5)}\end{array}$ & $\begin{array}{c}\text { Quasi- } \\
\text { experimental } \\
\text { Study }\end{array}$ & $\begin{array}{l}\text { Establish the viability } \\
\text { of DT; } \\
\text { Determine its impact } \\
\text { on measures of } \\
\text { psychological and } \\
\text { existential suffering. }\end{array}$ & $\begin{array}{l}\mathrm{n}=100 \text { terminal } \\
\text { cancer patients with life } \\
\text { expectancy } \leq 6 \text { months; } \\
\text { (97\% cancer and } 3 \% \\
\text { non-malignant terminal } \\
\text { conditions). }\end{array}$ & $\begin{array}{l}\text { DT had good satisfaction rates, utility, increasing } \\
\text { sense of dignity }(p=0.085) \text {, purpose, meaning and } \\
\text { will to live, improved self-reported depressing mood } \\
(p=0.05) \text {, suffering }(p=0.023) \text { and quality of life } \\
(p=0.049) \text {. Reported that the DT helped them or } \\
\text { would help the families. }\end{array}$ \\
\hline A9 & $\begin{array}{l}\text { Chochinov } \\
\text { et al., } \\
2011_{-} \\
\text {Canada }^{(21)}\end{array}$ & $\begin{array}{l}\text { Randomized } \\
\text { Clinical Trial }\end{array}$ & $\begin{array}{l}\text { Compare DT with } \\
\text { palliative care and } \\
\text { patient-centered care } \\
\text { standards regarding } \\
\text { the dimensions of } \\
\text { distress (depression } \\
\text { and suffering), quality } \\
\text { of life and dignity. }\end{array}$ & $\begin{array}{l}\mathrm{n}=326 \text { patients in } \\
\text { palliative care with } \\
\text { life expectancy } \leq 6 \\
\text { months, submitted to } \\
\text { DT ( } \mathrm{n}=108) \text {, Patient- } \\
\text { Centered Care } \\
(\mathrm{n}=107) \text { and Palliative } \\
\text { Care } \\
(\mathrm{n}=111) ;(95.8 \% \\
\text { neoplasia and } 4.3 \% \\
\text { non-malignant terminal } \\
\text { conditions). }\end{array}$ & $\begin{array}{l}\text { Patients who received DT reported better indices } \\
\text { in: utility }(p<0.001), \text { quality of life }(p<0.001) \text {, } \\
\text { sense of dignity }(p=0.002) \text {, satisfaction }(p<0.001) \text {, } \\
\text { family assessment }(p<0.001) \text {. Reported that the DT } \\
\text { would help them or their families }(p<0.001) \text {. There } \\
\text { were also improvements in spiritual well-being } \\
(p=0.006) \text {, a decrease in sadness or depression } \\
(p=0.009) \text {. Better end-of-life quality experience. } \\
\text { The ability to decrease depression, the wish for } \\
\text { death or suicide was not proven. }\end{array}$ \\
\hline A10 & $\begin{array}{l}\text { Houmann } \\
\text { et al., } \\
2014- \\
\text { Denmark }^{(22)}\end{array}$ & $\begin{array}{l}\text { Quasi- } \\
\text { experimental } \\
\text { Study }\end{array}$ & $\begin{array}{l}\text { Evaluate and explore } \\
\text { the effectiveness of } \\
\text { Dignity Therapy (DT) } \\
\text { for patients with } \\
\text { incurable cancer. }\end{array}$ & $\begin{array}{l}\mathrm{n}=80 \text { patients with } \\
\text { incurable cancer; } 100 \% \\
\text { cancer with average } \\
\text { survival of } 4 \text { months. }\end{array}$ & $\begin{array}{l}\text { DT was considered: satisfactory and having useful } \\
\text { potential to help for the family ( } 73-89 \%) \text {, with an } \\
\text { increase in the sense of dignity, purpose and the } \\
\text { will to live }(47-56 \%) \text {, making life more meaningful } \\
\text { with reduction in pain and improvement of family } \\
\text { assessment ( } 25 \text { to } 43 \%) \text {. At first there was an } \\
\text { increase in depression score and a decreased overall } \\
\text { quality of life; in the second evaluation there was an } \\
\text { increase in the sense of dignity and it reduced the } \\
\text { feeling of being a burden. }\end{array}$ \\
\hline
\end{tabular}

An analysis of the selected study designs showed: five randomized controlled trials (50\%), three with a moderate level of evidence and two with a high level of evidence ${ }^{(6,15-16,19,21)}$, one controlled clinical trial (10\%) with a moderate level of evidence ${ }^{(20)}$, four quasi-experimental studies (40\%), being two with low and two very low levels of evidence ${ }^{(5,17-18,22)}$. Chart 3 shows the detail of the scores of the studies included in the review, according to the GRADE system ${ }^{(14)}$.

Chart 3 - Level of study evidence, according to the GRADE system ${ }^{(22)}$ - São Paulo, 2015.

\begin{tabular}{|c|c|c|c|c|c|c|c|c|c|c|}
\hline \multirow[t]{2}{*}{ Author/Year } & \multirow[t]{2}{*}{ Study design } & \multicolumn{5}{|c|}{ Reducing factors } & \multicolumn{3}{|c|}{ Increasing factors } & \multirow[t]{2}{*}{ Level of evidence } \\
\hline & & $\mathbf{I}$ & II & III & IV & $\mathbf{V}$ & VI & VII & VIII & \\
\hline Julião et al., $2013^{(6)}$ (A1) & $\mathrm{CRCT}^{\mathrm{a}}$ & 1 & / & / & -1 & / & / & / & / & $\begin{array}{c}\text { Moderate } \\
3\end{array}$ \\
\hline Julião et al., 2014(15) (A2) & $\mathrm{CRCT}^{\mathrm{a}}$ & 1 & / & / & -1 & / & / & / & / & $\begin{array}{c}\text { Moderate } \\
3\end{array}$ \\
\hline Hall et al., $2011^{(16)}(\mathrm{A} 3)$ & $\mathrm{CRCT}^{\mathrm{a}}$ & / & / & / & / & / & / & / & / & $\underset{4}{\mathrm{High}}$ \\
\hline Johns et al., $2013^{(17)}(\mathrm{A} 4)$ & $\mathrm{QES}^{\mathrm{c}}$ & / & / & / & / & -1 & / & / & / & $\begin{array}{c}\text { Very low } \\
1\end{array}$ \\
\hline Vergo et al., 2014(18) (A5) & $\mathrm{QES}^{\mathrm{c}}$ & / & / & / & / & -1 & / & / & / & $\begin{array}{c}\text { Very low } \\
1\end{array}$ \\
\hline Rudilla et al., 2014(19) (A6) & $\mathrm{CRCT}^{\mathrm{a}}$ & -1 & l & / & / & -1 & +1 & / & l & $\begin{array}{c}\text { Moderate } \\
3\end{array}$ \\
\hline Rudilla et al., 2015 $5^{(20)}(\mathrm{A} 7)$ & $\mathrm{CCT}^{\mathrm{b}}$ & -1 & / & / & / & / & / & / & / & $\begin{array}{c}\text { Moderate } \\
3\end{array}$ \\
\hline Chochinov et al., $2005^{(5)}$ (A8) & $\mathrm{QES}^{\mathrm{c}}$ & 1 & / & / & / & / & / & / & / & $\begin{array}{l}\text { Low } \\
2\end{array}$ \\
\hline Chochinov et al., 2011(21) (A9) & $\mathrm{CRCT}^{\mathrm{a}}$ & 1 & / & / & / & / & / & / & / & $\begin{array}{c}\mathrm{High} \\
4\end{array}$ \\
\hline Houmann et al., 2014 ${ }^{(22)}(\mathrm{A} 10)$ & QES $^{c}$ & 1 & / & / & / & / & / & / & / & $\begin{array}{l}\text { Low } \\
2\end{array}$ \\
\hline
\end{tabular}

${ }^{a}$ Controlled Randomized Clinical Trial (CRCT) / b Controlled Clinical Trial (CCT) / c Quasi-Experimental Study (QES).

I - Risk of bias; II - Inconsistency; III - Indirect Evidence; IV - Imprecision; V - Publication Bias; VI - Effect size; VII - Dose-response gradient; VIII - Possible residual confusion.

*The bars represent that in the given aspect the study did not obtain a reduction or increase in scores. 
Group 1 - Patients of Palliative Care With ADVANCED/TERMINAL DISEASE IN A HOSPITALIZATION UNIT

Two randomized controlled trials with a moderate level of evidence were included in this group. The patients' profile in these studies was: terminal patients with life expectancy $\leq$ 6 months, mostly including oncological diseases of diverse origins and non-oncological diseases (amyotrophic lateral sclerosis and trigeminal neuralgia in both). The patients were cared for at a hospice units specialized in palliative care in both studies; they were allocated to two groups with one being DT, and the other where patients received standard palliative care therapy in which the institution's conventional palliative care was administered by a multiprofessional specialized team ${ }^{(6,15)}$.

In study A1, the patients were evaluated before the intervention, presenting high rates of depression and anxiety. The results were statistically significant for depression (with the exception of the $30^{\text {th }}$ day $-p=0.097$ ) and for anxiety at all follow-up periods ${ }^{(6)}$. In A2, patients also had higher rates of psychosocial distress in the initial evaluation, but the results were statistically significant at all follow-up periods for the two analyzed variables ${ }^{(15)}$.

\section{Group 2 - Outpatients/Patients In Palliative CARE WITH ADVANCED/TERMINAL. DISEASE}

In this group, five studies were included: a randomized controlled trial with a high level of evidence ${ }^{(16)}$, a randomized controlled trial with a moderate level ${ }^{(16)}$, a controlled clinical trial $^{(20)}$ with a moderate level of evidence, and two quasiexperimental studies with very low levels of evidence ${ }^{(17-18)}$. The profile of the patients included in these studies was: outpatients who attended the services for performing procedures and consultations and/or those followed by multiprofessional home visiting teams and/or nursing homes, with oncological and non-oncological diseases (unspecified) ${ }^{(16-20)}$.

In A3, patients were allocated to the intervention group (DT) and to the control group, in which they received the institution's standard palliative care therapy. All patients were older adults living in nursing homes with oncological and non-oncological diseases (unspecified). In the potential for efficacy (suffering related to dignity, loss of hope, depression, quality of life), there was only a small effect on reduction of depression (effect size $=0.05)$ and quality of life (effect size $=$ 0.02 ) in favor of DT, following 1 week post-intervention ${ }^{(16)}$.

For outcome acceptability, a significant difference was observed in the comparison with control group for the variables making life more meaningful and family support both at 1 week follow-up $(p=0.02)$ and at 8 weeks post-intervention $(p=0.01)$. The effect of DT on utility (effect size $=$ 0.55 ), increased sense of purpose (effect size $=0.53$ ), will to live (effect size $=0.39)$ and decreased pain (effect size $=$ 0.34 ) was considered moderate at 8 weeks follow-up. The last outcome evaluated was viability, where the number of visits to complete the initial intervention (DT) was one visit (93\%) and to complete the instrument was 1 to 5 visits on average ${ }^{(16)}$.

In A4, the patients were women with metastatic cancer. DT was useful for themselves and their families in $75 \%$ of patients, increasing the meaning of life, sense of dignity and reduced suffering. There was $100 \%$ satisfaction, as the patients considered the generated document very useful. In comparing the measures performed before and after the intervention, however, there was an increase in levels of depression and anxiety ${ }^{(17)}$.

In study A5, patients who were not hospitalized (outpatients) and who went to services only to perform palliative chemotherapy were evaluated. For the outcome of viability, benefits of DT were observed for all variables (satisfaction, utility, increased sense of meaning, purpose, dignity and increased will to live). For the outcome of physical symptoms (pain, tiredness, nausea, drowsiness, appetite, dyspnea), only appetite improved after DT. Psychosocial symptoms (anxiety, depression, feeling of well-being, classification and satisfaction with quality of life and distress) were not affected by DT. The most satisfactory results were related to clinical outcomes, with increased acceptance of death one month after DT (57\%) and improvement in the choice for treatments that did not prolong life $(58 \%)^{(18)}$.

In study A6 with a quasi-experimental design, patients/ outpatients with neoplasia living in the home were evaluated. Therapeutic counseling (TC) consisted of an approach developed to facilitate communication between the health professional and the patients, based on three pillars: technical knowledge, attitudes and relationship strategies (assertive communication, personal self-regulation skills and problemsolving skills) with the goal of improving psychosocial symptoms ${ }^{(19)}$. Both reduced suffering (DT $p<0.001 ; \mathrm{TC} p=0.001$ ), increased quality of life (DT $p=0.000$; TC $p=0.009$ ) and decreased existential distress (DT $p=0.003, \mathrm{TC} p<0.001$ ). Regarding the effect size of these variables, $\mathrm{TC}$ was superior for quality of life $(\mathrm{DT}=1.69, \mathrm{TC}=3.47)$ and existential distress $(\mathrm{DT}=1.94, \mathrm{TC}=3.34)$ and $\mathrm{DT}$ was higher for reducing suffering $(\mathrm{DT}=2.74, \mathrm{TC}=2.50)^{(19)}$.

In study A7, DT was also compared to TC in patients at home using a controlled clinical trial with a moderate level of evidence. In this case, a significant difference was observed between interventions only for the variable anxiety $(p=0.022)$, in favor of TC (effect $=0.65$, considered moderate). For the variables: peace of $\operatorname{mind}(\mathrm{DT} p<0.001 / \mathrm{effect}=$ 1.11; TC $p<0.001 /$ effect $=1.15)$, anxiety (DT $p=0.001$ effect $=0.58$; TC $p=0.001 /$ effect $=0.65)$, intrapersonal spirituality (DT $p<0.001 /$ effect $=1.12 ; \mathrm{TC} p<0.001 / \mathrm{effect}=$ $1.31)$ and transpersonal spirituality $(\mathrm{DT} p<0.001 / \mathrm{effect}=$ 0.83 ; TC $p<0.001 /$ effect $=1.49$ ), a significant difference with a large effect size was also observed, but in favor of $\mathrm{TC}^{(20)}$.

Spirituality is defined as the human quest to transcend the self to find meaning and purpose through connection with others, with nature and/or "a Supreme Being," which may or may not include religious institutions. Intrapersonal spirituality encompasses the elements of self-discovered spirituality, involving the search for meaning and purpose; interpersonal spirituality involves interpersonal relationships, through the relationship between the personal journey and other people's journeys; and transpersonal spirituality is related to ecoconsciousness, meaning the connection of the personal journey with nature, insofar as all aspects of life are interconnected ${ }^{(23)}$. 
Group 3 - AdmitTed AND NON=ADMITTED PATIENTS (INPATIENTS/OUTPATIENTS) IN PALLIATIVE CARE WITH AN ADVANCED/TERMINAL DISEASE

Three studies with quasi-experimental design and low level of evidence were included in this group. In these studies, the patients had a life expectancy of 4 to 6 months, most with advanced stage neoplasia of several origins and some patients with non-malignant terminal conditions (advanced stage of multiple organ failure) $)^{(5,21-22)}$.

In study A8, the viability analysis showed that $91 \%$ were satisfied or very satisfied with DT, $86 \%$ considering it useful or very useful, $60 \%$ indicating increased sense of dignity, $68 \%$ increased sense of purpose, $67 \%$ increased sense of meaning, $40 \%$ increased will to live and $81 \%$ reported that DT helped or would help their families. In the quantitative outcomes, post-intervention measures showed a significant reduction of suffering ( $p=0.023)$, and improvement in depressing mood $(p=0.05)$; however, loss of hope, wishing for death, anxiety and suicide were not affected by DT. In the same study, the patients who reported the greatest psychosocial distress at the start of the study were those who reported the greatest benefits from therapy, and especially for: quality of life $(p=$ $0.049)$, level of dignity $(p=0.021)$ and lower risk of suicide $(p=0.012)$ measures, with all significantly related to utility and satisfaction with therapy ${ }^{(5)}$.

In study A9, patients were randomly allocated into three different groups, with one for DT, one for standard palliative care therapy and one for patient-centered care. This study was considered as having a high level of evidence for being a well-defined, randomized controlled trial. In standard palliative care therapy, patients received standard/conventional therapy from institutions where they were hospitalized or from multiprofessional home-visiting teams. Patient-centered care is a supportive psychotherapeutic approach in which therapist-nurses guide patients to discussions focused on "here and now" issues; for example, participants answered questions about their illness associated with symptoms, and discussed what they were doing to solve their suffering. DT was superior to the two other approaches, showing significant utility $(p<0.001)$, quality of life $(p<0.001)$, sense of dignity $(p=0.002)$, satisfaction $(p<0.001)$ and improvement of family appreciation in relation to the patient indices $(p<0.001)$. In this study, patients also reported that DT helped or would significantly help their families $(p<0.001)$ in comparison to the other groups. In the group that received DT, an improvement in spiritual well-being $(p=0.006)$ and improvement in the patients' sadness or depression $(p=0.009)$ was also observed ${ }^{(21)}$.

In study A10, patients with advanced neoplasia were evaluated. As it consisted of a quasi-experimental study, it was considered as having a low level of evidence. The average survival time of patients was about 4 months. The patients were submitted to DT and evaluated about 30 days after the initial measurements, and at a second moment of about 60 days after the initial measurements. DT was considered useful, satisfactory and providing potential help for family members (73\%); furthermore, DT increased sense of dignity, purpose and will to live, making life more meaningful for $49 \%$ of those assessed. The 60 -day post-assessment showed an increase in sense of dignity and a decrease in the feeling of being a burden to others, revealing that DT had prolonged effects for these variables. Initially, there was an increase in depression scores, but improvements were observed for this variable in the 60-day evaluation ${ }^{(22)}$.

\section{DISCUSSION}

The studies included in this review evaluated physical, psychosocial and spiritual effects of dignity therapy, although not all articles evaluated all three aspects.

More severely afflicted patients at the start of the study may present impairment with the application of DT, since they can build a distorted view of themselves. However, the patients in $\mathrm{A} 1$ and $\mathrm{A} 2$ presented significant improvement in the variables of depression and anxiety, even in the presence of these conditions. In A1, the lack of prolonged effect of DT for depression following the $30^{\text {th }}$ day may suggest an insufficient number of DT sessions ${ }^{(6,15)}$.

In study A3, the DT-generated document had good acceptability, so much so that patients chose to turn it in before their own death. Also, the evaluation of those receiving the document was also satisfactory in that it provided better patient insight and pleasant discussions about the highlighted memories. In this study, the levels of distress measured before the intervention were relatively low and the patients reported a good quality of life; in that sense, there was little room for improvement, which may represent a limitation ${ }^{(16)}$.

The A4 study sample was small $(\mathrm{n}=10)$ and only four patients completed pre and post-intervention measures, associated with clinical deterioration throughout the followup. Thus, the conclusions of this study should be observed cautiously, especially because it was classified with a very low level of evidence, with little confidence in the effect estimate. Thus, there is no way of stating whether the application of DT could increase levels of anxiety and depression in terminal patients ${ }^{(17)}$.

In A5, DT showed good results mainly for improving the acceptance of death and end-of-life goals regarding treatment and care; but because it was a quasi-experimental study, there was no control group for comparison. Therefore, it is not possible to determine if the improvement is related to the DT or the passage of time; in addition, it was a very small sample (only nine patients). Furthermore, many of the patients included in the study had never had a talk with the health team about prognosis, design, or therapeutic goals, and in providing that conversation, DT resulted in better acceptance of death and better end-of-life choices ${ }^{(21)}$.

In $\mathrm{A} 6$ and $\mathrm{A} 7$, both therapies showed evidence that they can improve the well-being of patients in palliative care living in the home. Therapeutic counseling seems to exert more benefits than DT for the variables of anxiety, resilience, and depression. The patients submitted to DT presented a significant increase in depression after the intervention. The authors state that there are components of therapeutic counseling contained in dignity therapy, 
which makes them similar, justifying the similarity of results between them and the lack of significant difference between the interventions ${ }^{(19-20)}$.

Study A8 presented good results on the acceptance of DT by inpatients and outpatients. The authors emphasized the importance of psychotherapy that is highly referred to as a potential help for family members (81\%), since feeling that DT would help family members significantly correlated with increased sense of meaning $(p<0.001)$, sense of purpose $(p<0.001)$, accompanied by a decrease in suffering $(p=0.001)$. That is, the patients feeling that DT could help their families, even after their deaths, helped improve the end-of-life experience ${ }^{(5)}$.

Study A9 showed that DT increased the quality of the end-of-life experience, with the ability to help the patients' families. However, this study did not evaluate the measures of suffering and distress before the interventions were performed. This initial evaluation could have improved the analysis of the differences between the three groups in the study, based on pre and post-intervention changes, allowing to hypothesize about the relationship between the initial level of anxiety in patients and the success of $\mathrm{DT}^{(21)}$.

In study A10, the patients most severely affected by psychosocial suffering were prevented from entering the study due to the exclusion criteria, and therefore there is no way to know if the outcomes would be the same for this patient profile. In addition, patients chose to deliver the DT-generated document about 14 days after the intervention, but when they had close relatives who were children, they had difficulty delivering and addressing the issue, so further studies should be conducted to determine the benefit of DT for patients who have children as close relatives ${ }^{(22)}$.

In general, a limitation of applying DT in studies is the loss in follow-up of patients during the pre- and post-intervention evaluations, since patients are in the terminal phase of life, and invariably their health conditions deteriorate, which makes it impossible for them to participate in the study due to lack of conditions or death.

Support for family members deserves special mention, since psychotherapies are focused on patients and their improvement outcomes, and most of the time they do not address family, friends and caregivers. The World Health Organization in its definition of palliative care advocates that all aspects of care should be addressed, including the psychosocial aspects. By improving family support, there is improvement in the end-of-life experience for patients, as evidenced by studies ${ }^{(7)}$. Dignity therapy seems to exert a good influence on the family support variable, since this improvement was pointed out in five studies with one presenting a moderate level of evidence and one a high level, meaning an estimate of approximate effect of the true effect $^{(5,16-17,21-22)}$. Thus, it may be the therapy of choice to improve these aspects.

In addition, DT appears to be well accepted by patients. It was identified as satisfactory in five studies ${ }^{(5,17-18,21-22)}$, and useful in six studies, with levels of evidence ranging from very low to high ${ }^{(5,16-18,21-22)}$. Increased dignity was noted in five studies ${ }^{(5,15,20-22)}$, quality of life in four studies ${ }^{(15-17,19)}$, and decreased suffering was observed in six studies ${ }^{(5,16-17,19-20)}$. In other words, DT presented good levels of acceptance by inpatients and outpatients, both with oncological and non-oncological diseases and with reduced life expectancy. However, there is the need for further studies to evaluate the usefulness of therapy for non-malignant pathologies, since it was a minority in the studies evaluated. Although DT was designed with the intention of improving the patients spiritual issues, only two studies showed improvement in this aspect after DT, with a level of evidence of moderate to high ${ }^{(20-21)}$.

Regarding the psychosocial distress variables, therapeutic counseling was superior to DT in the two studies comparing these variables ${ }^{(19-20)}$. In two studies evaluating a reduction in depression and anxiety by DT, there was an improvement in scores, even for patients who were more severely distressed at the beginning of the study ${ }^{(6,16)}$. In another three studies there was a decrease in depression after the intervention with $\mathrm{DT}^{(5,16,21)}$. Although controversial, the application of DT appears to have had good effects on depression, with less impact on anxiety. However, larger impact studies and larger populations are needed to confirm the improvement or worsening of the psychosocial distress variables in monitoring the effectiveness of DT.

Further studies are needed to prove the sustained benefit of the therapy, as DT presented a sustained benefit in one study, however in another the improvement provided to depression symptoms was not sustained until the $30^{\text {th }}$ day of intervention $^{(6,16)}$. None of the articles analyzed in this review were published in Brazil, indicating that this review may represent an initial step for the development of intervention studies in this area within Brazil.

Furthermore, none of the experimental articles analyzed were published by nurses, although these professionals have developed theoretical studies in this area. Considering the role of nurses in palliative care, we can note that it is a field with great potential for research development, especially intervention studies, which can bring advances to end-oflife/hospice care.

This study has limitations, which should be pointed out. The inclusion of articles only in Portuguese, English and Spanish might have excluded important studies from other cultures/languages.

\section{CONCLUSION}

Dignity Therapy is a brief, individualized psychotherapy designed to address the psychosocial, spiritual, and physical issues of terminally ill patients. There is high and moderate evidence supporting its application, with good effect estimates especially related to satisfaction, utility, increased dignity, meaning of life, sense of purpose and will to live, with a significant decrease in suffering. However, the performance of dignity therapy for the variables of psychosocial distress (depression and anxiety) is still controversial, requiring further evidence of greater impact. The effect of therapy on family support was highly satisfactory, demonstrating that DT can be useful for both patients and their families, improving the end-of-life experience. Physical symptoms do 
not seem to be directly influenced by DT, although many symptoms are subjective and can be indirectly improved by the impact of DT on feelings and emotions. Spirituality also did not experience much impact of improvement reported by patients, and it should also be further evaluated in larger impact studies.

\section{RESUMO}

Objetivo: Analisar as evidências sobre os efeitos da terapia da dignidade para pacientes em fase terminal de vida. Método: Revisão sistemática da literatura realizada em seis bases de dados na estratégia de busca. Os critérios de inclusão foram estudos primários, excluindo-se revisões da literatura (sistemáticas ou não) e artigos conceituais. Resultados: Dez artigos foram analisados quanto ao método, aos resultados e nível de evidência. Nos estudos com maior nível de evidência, a terapia da dignidade melhorou o senso de significado, propósito, vontade de viver, utilidade, qualidade de vida, dignidade e apreciação familiar. Os efeitos não estão bem estabelecidos em relação à depressão, ansiedade, espiritualidade e aos sintomas físicos. Conclusão: Os estudos de nível de evidência de moderado a alto demonstraram aumento do senso de dignidade, vontade de viver e senso de propósito. Mais estudos devem ser desenvolvidos para ampliar o conhecimento sobre a terapia da dignidade.

\section{DESCRITORES}

Cuidados Paliativos; Doente Terminal; Psicoterapia Breve; Qualidade de Vida; Enfermagem Holística; Revisão.

\section{RESUMEN}

Objetivo: Analizar las evidencias acerca de los efectos de la terapia dignidad para pacientes en fase terminal de vida. Método: Revisión sistemática de la literatura llevada a cabo en seis bases de datos en la estrategia de búsqueda. Los criterios de inclusión fueron estudios primarios, excluyéndose las revisiones de literatura (sistemáticas o no) y los artículos conceptuales. Resultados: Diez artículos fueron analizados en cuanto al método, los resultados y el nivel de evidencia. En los estudios con mayor nivel de evidencia, la terapida de la dignidad mejoró el sentido de significado, propósito, ganas de vivir, utilidad, calidad de vida, dignidad y estimación familiar. Los efectos no están bien planteados con respecto a la depresión, ansiedad, espiritualidad y los síntomas físicos. Conclusión: Los estudios de nivel de evidencia de moderado a alto demostraron incremento del sentido de dignidad, ganas de vivir y sentido de propósito. Se deben desarrollar más estudios a fin de ampliar el conocimiento acerca de la terapia de la dignidad.

\section{DESCRIPTORES}

Cuidados Paliativos; Enfermo Terminal; Psicoterapia Breve; Calidad de Vida; Enfermería Holística; Revisión.

\section{REFERENCES}

1. Kant I, Galvão P. Fundamentação da metafísica dos costumes. Lisboa: Edições 70; 2007.

2. Van Der Maas PJ, Van Delden JJ, Pijnenborg L, Looman CW. Euthanasia and other medical decisions concerning the end of life. Lancet. 1991;338(8768):669-74

3. Chochinov HM, Hack T, Hassard T, Kristjanson LJ, McClement S, Harlos M. Dignity in the terminally ill: a cross-sectional, cohort study. Lancet. 2002;360(9350):2026-30.

4. Chochinov HM, Hack T, McClement S, Kristjanson L, Harlos M. Dignity in the terminally ill: a developing empirical model. Soc Sci Med. 2002;54(3):433-43.

5. Chochinov HM, Hack T, Hassard T, Kristjanson LJ, McClement S, Harlos M. Dignity therapy: a novel psychotherapeutic intervention for patients near the end of life. J Clin Oncol. 2005;23(24):5520-5.

6. Julião M, Barbosa A, Oliveira F, Nunes B, Carneiro, AV. Efficacy of dignity therapy for depression and anxiety in terminally ill patients: early results of a randomized controlled trial. Palliat Support Care. 2013;11(6):481-9.

7. World Health Organization (WHO). WHO Definition of palliative care [Internet]. Geneva: WHO; 2014 [cited 2014 Jan 20 ]. Available from: http://www.who.int/cancer/palliative/definition/en/

8. Instituto Nacional de Câncer José Alencar Gomes da Silva. Incidência de câncer no Brasil: estimativa 2016 [Internet]. Rio de Janeiro: INCA; 2016 [citado 2014 jan. 14]. Disponível em: http://www.inca.gov.br/estimativa/2016/

9. Instituto Brasileiro de Geografia e Estatística. Projeção da população do Brasil e Unidades da Federação: $2000-2030$ [Internet]. Rio de Janeiro: IBGE; 2016 [citado 2016 fev. 20]. Disponível em: http://www.ibge.gov.br/apps/populacao/projecao/

10. Malta DC, Moura LD, Prado RRD, Escalante JC, Schmidt MI, Duncan BB. Mortalidade por doenças crônicas não transmissíveis no Brasil e suas regiões, 2000 a 2011. Epidemiol Serv Saúde. 2014;23(4):599-608.

11. Moher D, Liberati A, Tetzlaff J, Altman DG. Preferred Reporting Items for Systematic Reviews and Meta-Analyses: the PRISMA statement. Ann Intern Med. 2009;151(4): 264-9.

12. Liberati A, Altman DG, Tetzlaff J, Mulrow C, Gøtzsche P, loannidis JPA, et al. The PRISMA statement for reporting systematic reviews and meta-analyses of studies that evaluate health care interventions: explanation and elaboration. PLoS Med. 2009;6(7):e1000100.

13. The Joanna Briggs Institute. Reviewers' manual. ed. 2014 [Internet]. Adelaide: JBI; 2014 [cited 2016 Feb 20]. Available from: http:// joannabriggs.org/assets/docs/sumari/reviewersmanual-2014.pdf

14. Balshem H. Grade guidelines: 3 rating the quality of evidence. J Clin Epidemiol. 2011;64(4):401-6.

15. Juliao M, Oliveira F, Nunes B, Vaz Carneiro A, Barbosa A. Efficacy of dignity therapy on depression and anxiety in Portuguese terminally ill patients: a phase II randomized controlled trial. J Palliat Med. 2014;17(6):688-95. 
16. Hall S, Goddard C, Opio D, Speck P, Higginson, IJ. Feasibility, acceptability and potential effectiveness of Dignity Therapy for older people in care homes: a phase II randomized controlled trial of a brief palliative care psychotherapy. Palliat Med. 2011;26(5):703-12.

17. Johns SA. Translating dignity therapy into practice: effects and lessons learned. Omega. 2013;67(1-2):135-45.

18. Vergo MT, Nimeir IH, Mulcahy M, Benson AB, Emanuel L. A feasibility study of dignity therapy in patients with stage IV colorectal cancer actively receiving second line chemotherapy. J Comm Support Oncol. 2014;12(12):446-53.

19. Rudilla D, Barreto P, Oliver A, Galiana L. Estudio comparativo de la eficacia del counselling y de la terapia de la dignidad en pacientes paliativos [resumen]. Med Paliat. 2016;23(4). DOI: 10.1016/j.medipa.2014.09.005

20. Rudilla D, Galiana L, Oliver A, Barreto P. Comparing counseling and dignity therapies in home care patients: a pilot study. Palliat Support Care. 2015;14(4):321-9.

21. Chochinov HM, Kristjanson LJ, Breitbart W, McClement S, Hack TF, Hassard T, et al. Effect of dignity therapy on distress and end-of-life experience in terminally ill patients: a randomised controlled trial. Lancet Oncol. 2011;12(8):753-62.

22. Houmann LJ, Chochinov HM, Kristjanson LJ, Petersen MA, Groenvold M. A prospective evaluation of Dignity Therapy in advanced cancer patients admitted to palliative care. Palliat Med. 2013;28(5):448-58.

23. Buck HG. Spirituality: concept analysis and model development. Holist Nurs Pract. 2006;20(6):288-92. 